\title{
Domestic Electric Power Generator Usage and Residents Livability Milieu in Ogbomoso, Nigeria
}

\author{
Akindele O. Akin \\ Department of Urban and Regional Planning \\ Ladoke Akintola University of Technology, Ogbomoso, Oyo State, Nigeria \\ Tel: 234-803-809-3456Ｅ-mail: oaakindele37@lautech.edu.ng \\ Adejumobi D. O. \\ Department of Urban and Regional Planning \\ Ladoke Akintola University of Technology, Ogbomoso, Oyo State, Nigeria
}

Received: January 6, 2017 Accepted: March 7, 2017

doi:10.5296/emsd.v6i1.10941ＵRL: https://doi.org/10.5296/emsd.v6i1.10941

\begin{abstract}
.
Incessant electric power failures have forced Nigerian residents into extensive use of electric power generator. This implicates a host of environmental livability glitches. This study therefore appraises the livability implications of domestic usage of electric power generators. The relative incidence of generator use was appraised. Residents' livability was also assessed across the three recognizable residential densities of the city having 20 political wards. Out of the total 561, 56 urban blocks (10\%) were sampled. A questionnaire was administered to 511 respondents using a multi stage approach. Noise dosimeter was used to measure the noise level. Likert scaling method was used in the transformation of ordinal data into ratio or interval data. Regression analysis was used to explain the relationship between the relative incidence of electric generator use (GUI) and the relative level of residents' livability (RLI) in the study. A high level incidence of power outage (81\%) was observed to have encouraged a high incidence $(78.6 \%)$ of electric generator use. There was observed a reliable relationship between relative incidence of electric generator use and residents' livability $(\mathrm{R}=-811, \mathrm{P}$ $=.000$ ). Economic, health and social components (in the order of listing) are affected by the use of electric generators. The study thus recommends physical, environmental, legal and administrative resolutions to eliminate the negative effects of electric power generator use.
\end{abstract}

Keywords: Electric power generator, Basic utility, Pollution, Livability, Nigeria 


\section{Introduction}

The issue of electric power generation in Nigeria over the years is exasperating. The country is experiencing the worst electric crisis among its contemporaries (World Bank, 2004); currently generating 4,500 megawatts of power (for more than $180 \mathrm{M}$ population) as against the needed 30,000 ( $15 \%$ of total power required). This put actual electrification at $2 \%$ (Nanaghan, 2009). The major alternative that Nigerians shifted to is the use of electric power generators. Nigeria therefore spends $15 \%$ of its annual budget to import diesel. Aside commercial and industrial consumption, as at 2009; more than six million Nigerians owns power generating set and spent a staggering 1.56 trillion ( $\$ 13.35$ Million) to fuel them in a year (Nanaghan, 2009). More than $85 \%$ rely on only generator costing average of $20 \mathrm{M}$ further loss as variable cost. Businesses, manufacturers, and banks among others, spend between $30-40 \%$ of their revenue on diesel to generating electricity. Electricity crisis remains key infrastructural development bottleneck and livability hindrance today.

Combustion of fossil fuels is responsible for more than $75 \%$ of the increase in atmospheric carbon dioxide (Chambers et al, 2000; UN, 2011). A major way of burning fossil fuel in Nigeria after automobiles is through electric generator usage. It contaminates air, water, soil material which interferes with human health, the good quality of life, and natural functioning of the ecosystem. (Walker and Hay, 1999; Stansfeld, S.; Haines, M.; and Brown, B. 2000; Wakefield, 2002;Schdmit, 2005; Oyedepo, 2012; Afolayan et al, 2014). Fine particulate air pollutant is known to contribute to cardiovascular and lung disease, increasing the risk of heart attacks and a heart-related death. (Pichot, 1992)). Bronchitis pneumonia, chronic respiratory disease, lung cancer, heart disease, damage to the brain, nerves, liver, are also associated with the pollutants from generators.( Passchier and Passchier, 2000). The unwanted sound from generator can damage physiological and psychological health, causing annoyance and aggression, hypertension, high stress levels, tinnitus, hearing loss, sleep disturbances, and other harmful effects (Pichot, 1992, Kryter, 1994; Guy et al, 1999; Blumenthal, 2001; Schwatz et al, 2010; Seleye-Fubara et al, 2011). This study therefore analyses the significance of the usage of electric generators in Ogbomoso Nigeria.

Electricity among other technologies has come to be an indispensable part of our environment. Living without it can only be better imagined. Most other technologies are functionless without electricity and hence, the end of use of electric power generator is not in sight as there is no guarantee to get electricity from other sources. This leaves us with many important questions: is the rate at which generators are been used not high enough to be significant in environmental degradation? What are the real and imagined consequences of the incessant usage of generators? In regions where the use of generators has become a sine-qua-non, are there no measures that should be put in place as policy options to checkmate the attendant consequences of generator use? How serious are the damages already caused by generator use and what are the implications for the future? These and many other pertinent questions would be answered in this study. Answering the questions is hoped to fill certain gaps on how the energy sector competes with the natural environment and how the problems so created may be abated. 


\section{Macrothink}

\section{The Study Area}

Ogbomoso $\left(8^{\circ} 15^{\mathrm{i}} \mathrm{N}, 4^{\mathrm{o}} 14^{\mathrm{i}} \mathrm{E}\right)$ is a medium sized city, the second largest in Oyo state Nigeria. It locates at the border of the rain forest and the guinea savannah within the south-western Nigeria. The city is traversed by the only road that connects the North from the southwest. It is $51 \mathrm{~km}$ and $53 \mathrm{~km}$ from Ilorin and Oyo respectively. The city performs high order functions including the fact that it is a University town. This evidences the land use diversification and the necessity to use electric power in making ends meet for the avalanche of diversified population.

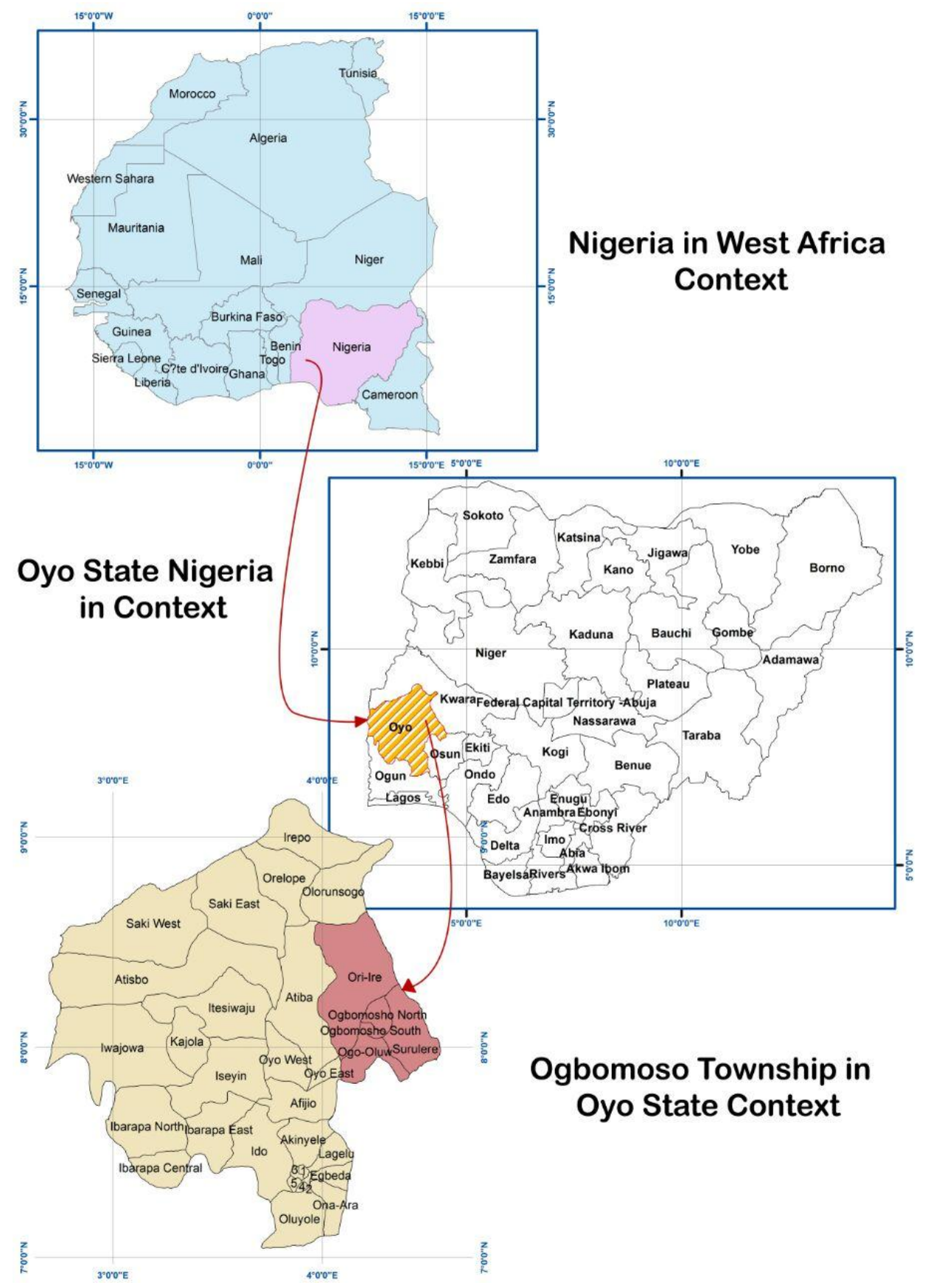

Figure 1. Ogbomoso within West-Africa, Nigeria and Oyo State 


\section{Methodology}

Primary and secondary data were used. Out of the total (561), $56(10 \%)$ urban blocks were sampled across the three recognizable residential densities in the 20 political wards of the town; and using a multi stage approach, a questionnaire was administered to 511 respondents eliciting information on electric generator usage and residents livability. Air samplers were used to investigate air pollution due to generator use. At each time, sequential multiple sampler or automatic impingers was used to take samples for two hours. The sampling cycle is activated by a clock mechanism. Air is drawn through the device by a motor driven pump equipped with a filter to remove particulate matter. Following the collection, samples were sent to the laboratory for analysis Noise decimeter was also used to A method reminiscent of Likert scaling was used to scale ordinal data (Afon, 2003), making them amenable to parametric testing. For each ward, the number of respondents multiplied by 4 is the maximum point achievable from each variable. This was used to standardize the weighing of the responses from the residents. The total score for each variable, divided by the maximum point achievable multiplied by 100 becomes the standardized score for each variable. A mean average was computed for use as general mean for all the variables on the table. Thus, each composite figure is given by:

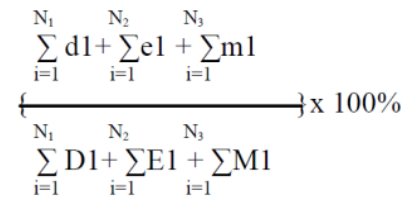

Where: $\mathrm{N}_{1}, \mathrm{~N}_{2}$ and $\mathrm{N}_{3}$ are the variables selected for scaling, $\mathrm{d}$, e and $\mathrm{m}$ are the actual score of the variables and D, E and $\mathrm{M}$ are the maximum point that may be scored by the variables.

Regression analysis was used to explain the relationship between usage of electric generators and residents livability in the study.

\section{Discussion of Findings}

Electric power generators are extensively used in the study. The chi-square test ( $\mathrm{P}$ value $=.103$ ) suggests that there is no significant difference in the usage of generators across the wards. However, there were relative differences in the incidence of electric generator usage across the wards sampled. High density areas with a higher incidence of commercial and industrial uses translating into high density, poorly maintained, smaller, soot producing electric generators followed by the medium and then the low density areas. Low density area residents have more silent, bigger and more maintained electric generators. So, the higher the building and human density, the higher is the incidence of electric generator usage. 


\section{Macrothink}

Table 1. Incidence of Electric Power Generator Use.

\begin{tabular}{|c|c|c|c|c|c|c|c|c|c|c|c|c|c|c|c|c|c|c|c|c|c|}
\hline Variable/wards & 1 & 2 & 3 & 4 & 5 & 6 & 7 & 8 & 9 & 10 & 11 & 12 & 13 & 14 & 15 & 16 & 17 & 18 & 19 & 20 & $\mathbf{X}^{2}$ \\
\hline Power Outage & 48 & 37 & 38 & 38 & 40 & 39 & 33 & 45 & 45 & 44 & 43 & 44 & 45 & 41 & 40 & 45 & 45 & 43 & 46 & 44 & .124 \\
\hline Gen Possession & 78 & 62 & 71 & 74 & 84 & 72 & 71 & 96 & 81 & 81 & 92 & 77 & 64 & 72 & 83 & 81 & 86 & 87 & 71 & 89 & .305 \\
\hline Use Regularity & 51 & 54 & 48 & 45 & 52 & 57 & 54 & 49 & 48 & 45 & 44 & 52 & 51 & 56 & 55 & 49 & 48 & 52 & 53 & 50 & .061 \\
\hline Work Hour/day & 9 & 10 & 6 & 6 & 7 & 10 & 9 & 9 & 8 & 9 & 8 & 5 & 6 & 7 & 9 & 9 & 8 & 8 & 7 & 10 & .052 \\
\hline Fuel used/day & 5 & 3 & 2 & 7 & 4 & 5 & 6 & 5 & 5 & 4 & 10 & 5 & 5 & 4 & 8 & 6 & 7 & 9 & 5 & 6 & .051 \\
\hline No in Building & 1.7 & 1.4 & 1.8 & 1.4 & 1.6 & 1.4 & 1.3 & 1.1 & 1.1 & 1.2 & 1.6 & 1.2 & 1.6 & 1,3 & 1,4 & 1.4 & 1.6 & 1.3 & 1.4 & 1.1 & .045 \\
\hline No of Gen Used & 3 & 2 & 4 & 4 & 3 & 4 & 3 & 4 & 4 & 3 & 2 & 3 & 3 & 5 & 5 & 3 & 3 & 4 & 4 & 3 & .068 \\
\hline Age (Month) & 32 & 39 & 38 & 41 & 40 & 35 & 34 & 35 & 27 & 33 & 31 & 37 & 33 & 34 & 36 & 34 & 37 & 33 & 34 & 36 & .002 \\
\hline Service Regularity & 2 & 3 & 1 & 3 & 2 & 3 & 1 & 5 & 2 & 3 & 4 & 3 & 2 & 2 & 2 & 4 & 3 & 2 & 2 & 5 & .051 \\
\hline Fuel type & 2 & 2 & 2 & 2 & 2 & 2 & 2 & 2 & 2 & 2 & 2 & 2 & 2 & 2 & 2 & 2 & 2 & 2 & 2 & 2 & .443 \\
\hline Distance to Building & 0.8 & 0.5 & 0.8 & 0.9 & 0.7 & 0.8 & 0.7 & 2.5 & 0.9 & 0.6 & 0.5 & 0.7 & 0.8 & 0.6 & 0.9 & 0.8 & 0.5 & 0.6 & 0.9 & 1.7 & .453 \\
\hline Domestic use & 61 & 68 & 66 & 69 & 67 & 79 & 77 & 92 & 81 & 73 & 71 & 69 & 65 & 69 & 69 & 76 & 78 & 67 & 68 & 89 & .133 \\
\hline Other use & 39 & 32 & 34 & 31 & 33 & 21 & 23 & 8 & 19 & 27 & 29 & 31 & 35 & 31 & 31 & 24 & 22 & 33 & 32 & 11 & .112 \\
\hline Mean & 26 & 24.1 & 24 & 24.8 & 25.9 & 25.3 & 24.2 & 27.2 & 24.9 & 25.1 & 26 & 25.4 & 24.1 & 25 & 26.3 & 25.8 & 26.2 & 26.3 & 25.1 & 26.8 & .114 \\
\hline
\end{tabular}

Key: Akata-1, Alafia oluwa-2, Arowomole-3, Caretaker-4, Idioro-5, Ijeru-6, Ijeru2-7, Low cost-8, Odokoto-9, Oke alapata-10. Adenike-11, Aaje-12, isale afon-13, agboyin-14, adiatu-15, high court-16, okelerin-17, sabo-18, isaleora-19, papa alajiki-20

This magnifies the risk posed by electric generator usage especially in the high density areas, as well as the connections between cities livability and equitable facility provision. Important inference to be drawn includes a cautious densification in cities and more holistic basic facility-urban development considerations. As cities gravitates towards compact city development, caution needs being exercised on the level of preparedness in terms of the availability and functionality of the required basic technologies and facilities. Inadequate provision of sustainable electricity has the propensity to trigger complex environmental problems as residents improvise for electric power on daily basis.

\subsection{Residents' Livability as a Result of Electric Generator Usage}

The cost of purchasing electric generators, daily burning of fuel for a minimum period of three hours, servicing of the electric generators and other subtle costs constrains residents to spending $42.24 \%$ of their income only for the purpose of generating electricity for a brief period in a day. 


\section{Macrothink \\ Environmental Management and Sustainable Development \\ ISSN 2164-7682 \\ 2017, Vol. 6, No. 1}

Table 2. Residents' Livability as a Result of Electric Generator Usage

\begin{tabular}{|c|c|c|c|c|c|c|c|c|c|c|c|c|c|c|c|c|c|c|c|c|}
\hline \multirow[t]{2}{*}{ Variables } & \multicolumn{20}{|c|}{ Area\% } \\
\hline & 1 & 2 & 3 & 4 & 5 & 6 & 7 & 8 & 9 & 10 & 11 & 12 & 13 & 14 & 15 & 16 & 17 & 18 & 19 & 20 \\
\hline \multicolumn{21}{|l|}{ Socio-economic effects } \\
\hline Expenditure on fuel & 24 & 26 & 24 & 23.5 & 26 & 25.5 & 23.5 & 28 & 26.5 & 22.5 & 24 & 26 & 24 & 23.5 & 26 & 25.5 & 23.5 & 28 & 26.5 & 22.5 \\
\hline Maintenance & 11.2 & 27.4 & 20.4 & 27.5 & 20.5 & 13.4 & 23.8 & 24.9 & 22.9 & 22.5 & 11.2 & 27.4 & 20.4 & 27.5 & 20.5 & 13.4 & 23.8 & 24.9 & 22.9 & 22.5 \\
\hline Electrical damaged & 17.5 & 21.5 & 23 & 20 & 17.5 & 20 & 18.5 & 21 & 13.5 & 18.5 & 17.5 & 21.5 & 23 & 20 & 17.5 & 20 & 18.5 & 21 & 13.5 & 18.5 \\
\hline Theft & 21 & 25.8 & 19.4 & 20.6 & 24 & 18 & 19.7 & 25 & 20.9 & 20.9 & 21 & 25.8 & 19.4 & 20.6 & 24 & 18 & 19.7 & 25 & 20.9 & 20.9 \\
\hline$\%$ Income spent & 42 & 33 & 35 & 35 & 43 & 37 & 35 & 46 & 39 & 39 & 42 & 43 & 35 & 25 & 43 & 27 & 25 & 26 & 19 & 19 \\
\hline Social effects & 14 & 14 & 10 & 11.5 & 10 & 11 & 11 & 14 & 8.5 & 10 & 14 & 14 & 10 & 11.5 & 10 & 11 & 11 & 14 & 8.5 & 10 \\
\hline Economic effect & 17.5 & 26.5 & 18 & 16 & 26.5 & 16 & 17.5 & 10 & 16 & 17.5 & 17.5 & 26.5 & 18 & 16 & 26.5 & 16 & 17.5 & 10 & 16 & 17.5 \\
\hline \multicolumn{21}{|l|}{ Environmental effects } \\
\hline Noise & 35.6 & 35.5 & 26.4 & 30.3 & 0 & 29.9 & 36.4 & 0 & 27.9 & 31.2 & 35.6 & 35.5 & 26.4 & 30.3 & 0 & 29.9 & 36.4 & 0 & 27.9 & 31.2 \\
\hline Smoke & 29.1 & 31.1 & 27.5 & 0 & 24.1 & 24.7 & 30.6 & 0 & 26.8 & 28.4 & 29.1 & 31.1 & 27.5 & 0 & 24.1 & 24.7 & 30.6 & 0 & 26.8 & 28.4 \\
\hline Wall defacing & 26.8 & 59.3 & 26.8 & 0 & 42.3 & 14 & 11.2 & 0 & 15.4 & 17 & 26.8 & 59.3 & 26.8 & 0 & 42.3 & 14 & 11.2 & 0 & 15.4 & 17 \\
\hline Env effects & 19 & 18.5 & 20 & 20 & 15 & 19.5 & 19.5 & 22 & 20.5 & 20.5 & 19 & 18.5 & 20 & 20 & 15 & 19.5 & 19.5 & 22 & 20.5 & 20.5 \\
\hline \multicolumn{21}{|l|}{ Health effects } \\
\hline electric shock & 20.8 & 35.5 & 8.4 & 4.2 & 10.5 & 2.1 & 8.4 & 27.1 & 16.6 & 4.2 & 20.8 & 35.5 & 8.4 & 4.2 & 10.5 & 2.1 & 8.4 & 27.1 & 16.6 & 4.2 \\
\hline Nervous diseases & 15.5 & 14.5 & 15.5 & 18.5 & 16 & 8.5 & 3.5 & 17 & 9.5 & 12.5 & 15.5 & 14.5 & 15.5 & 18.5 & 16 & 8.5 & 3.5 & 17 & 9.5 & 12.5 \\
\hline Smoke & 3.8 & 26.7 & 9.6 & 18.2 & 19.2 & 6.8 & 2 & 25 & 5.8 & 23.1 & 3.8 & 26.7 & 9.6 & 18.2 & 19.2 & 6.8 & 2 & 25 & 5.8 & 23.1 \\
\hline Hearing Loss & 0 & 41.7 & 0 & 8.4 & 16.7 & 4.2 & 0 & 20.9 & 0 & 0 & 0 & 41.7 & 0 & 8.4 & 16.7 & 4.2 & 0 & 20.9 & 0 & 0 \\
\hline Eye Irritation & 25.9 & 20.8 & 16.8 & 24.6 & 20 & 16.2 & 16.8 & 18.7 & 20 & 19.4 & 25.9 & 20.8 & 16.8 & 24.6 & 20 & 16.2 & 16.8 & 18.7 & 20 & 19.4 \\
\hline Respiratory Infection & 22.6 & 16.7 & 22.1 & 19.6 & 16.1 & 19 & 22 & 17.4 & 16.2 & 20.8 & 22.6 & 16.7 & 22.1 & 19.6 & 16.1 & 19 & 22 & 17.4 & 16.2 & 20.8 \\
\hline Throat Irritation & 4.4 & 33.7 & 30.4 & 30.4 & 27.1 & 26 & 18.5 & 0 & 0 & 21.8 & 4.4 & 33.7 & 30.4 & 30.4 & 27.1 & 26 & 18.5 & 0 & 0 & 21.8 \\
\hline Asthma & 27.4 & 22.1 & 23 & 0 & 24.4 & 23.7 & 25.8 & 38.7 & 4.2 & 27.4 & 27.4 & 22.1 & 23 & 0 & 24.4 & 23.7 & 25.8 & 38.7 & 4.2 & 27.4 \\
\hline Migraine & 4 & 44 & 57 & 0 & 56 & 18 & 16 & 0 & 16 & 20 & 4 & 44 & 57 & 0 & 56 & 18 & 16 & 0 & 16 & 20 \\
\hline Nausea & 31.2 & 19.2 & 24.7 & 0 & 22.5 & 21.1 & 29.3 & 0 & 29.1 & 27 & 31.2 & 19.2 & 24.7 & 0 & 22.5 & 21.1 & 29.3 & 0 & 29.1 & 27 \\
\hline Dizziness & 15 & 39.8 & 30.2 & 0 & 24.6 & 13.3 & 22.6 & 0 & 13.3 & 28.5 & 15 & 39.8 & 30.2 & 0 & 24.6 & 13.3 & 22.6 & 0 & 13.3 & 28.5 \\
\hline Fatigue & 19.4 & 32.2 & 38.7 & 0 & 25.8 & 9.6 & 6.4 & 10.2 & 0 & 35.5 & 19.4 & 32.2 & 38.7 & 0 & 25.8 & 9.6 & 6.4 & 10.2 & 0 & 35.5 \\
\hline Coma/death & 37.2 & 25.8 & 18.2 & 0 & 21.9 & 14.4 & 33.4 & 0 & 25.8 & 25.8 & 37.2 & 25.8 & 18.2 & 0 & 21.9 & 14.4 & 33.4 & 0 & 25.8 & 25.8 \\
\hline Lead Poisoning & 0 & 60 & 33.3 & 0 & 33.4 & 16.7 & 6.6 & 0 & 0 & 0 & 0 & 60 & 33.3 & 0 & 33.4 & 16.7 & 6.6 & 0 & 0 & 0 \\
\hline Eye problem & 8.4 & 71 & 50 & 0 & 62.5 & 0 & 0 & 0 & 0 & 0 & 8.4 & 71 & 50 & 0 & 62.5 & 0 & 0 & 0 & 0 & 0 \\
\hline Insomnia & 39.9 & 22.4 & 29.4 & 0 & 19.6 & 35 & 39.9 & 0 & 35.7 & 38.5 & 39.9 & 22.4 & 29.4 & 0 & 19.6 & 35 & 39.9 & 0 & 35.7 & 38.5 \\
\hline Effluence & 27 & 35.1 & 43.2 & 28.8 & 13.5 & 14.4 & 18 & 21.6 & 0 & 0 & 27 & 35.1 & 43.2 & 28.8 & 13.5 & 14.4 & 18 & 21.6 & 0 & 0 \\
\hline Health effect & 31.8 & 25.6 & 23.9 & 31.8 & 20.9 & 27.1 & 28.1 & 26.4 & 20.2 & 21.4 & 31.8 & 25.6 & 23.9 & 31.8 & 20.9 & 27.1 & 28.1 & 26.4 & 20.2 & 21.4 \\
\hline Electricity Regularity & 9 & 6.5 & 18.5 & 6 & 4 & 12.5 & 9.5 & 21 & 5 & 9 & 9 & 6.5 & 18.5 & 6 & 4 & 12.5 & 9.5 & 21 & 5 & 9 \\
\hline Frequency of Use & 23.5 & 25.5 & 25 & 20.5 & 26 & 26.5 & 24 & 20.5 & 23 & 20.5 & 23.5 & 25.5 & 25 & 20.5 & 26 & 26.5 & 24 & 20.5 & 23 & 20.5 \\
\hline
\end{tabular}

Sources: Author's field work, 2016.

Akata-1, Alafia oluwa-2, Arowomole-3, Caretaker-4, Idioro-5, Ijeru-6, Ijeru2-7, Low cost-8, Odokoto-9, Oke alapata-10.

Adenike-11, Aaje-12, isale afon-13, agboyin-14, adiatu-15, high court-16, okelerin-17, sabo-18, isaleora-19, papa alajiki-20 
These impoverish users and create various other problems for them. Usage of electric generator is a strong contributor to high poverty level in our cities. This is a serious livability problem. Generator produces loud noises (an average of $58.2 \mathrm{db}$ ) that are difficult to tolerate exceeding the maximum safe outdoor noise level of 55db (WHO,1986). The situation becomes worse with multiple generators within a plot size and worse still, a higher density of electric generators within a unit space. One sample t-test revealed a significant difference (at $\alpha=.01$ ) between the WHO stipulated standard for the tolerable outdoor noise level and the mean averages of the ambient noise levels obtainable from the areas sampled.

Table 3. Ambient Noise Level from Generators at Distances (Decibel)

\begin{tabular}{|l|l|l|l|l|l|l|l|l|l|l|l|l|l|l|l|l|l|l|l|l|l|}
\hline Distance & 1 & 2 & 3 & 4 & 5 & 6 & 7 & 8 & 9 & 10 & 11 & 12 & 13 & 14 & 15 & 16 & 17 & 18 & 19 & 20 & Mean \\
\hline $3 \mathrm{~m}$ & 82 & 83 & 82.8 & 86 & 85 & 84 & 84 & 72 & 84 & 83 & 84 & 84 & 81 & 81 & 80 & 84 & 85 & 86.7 & 78 & 78 & 84.6 \\
\hline $6 \mathrm{~m}$ & 79 & 78.9 & 80 & 79 & 78 & 79 & 78 & 77 & 78 & 78 & 79 & 78 & 78 & 78 & 79 & 78 & 79 & 79 & 78 & 76 & 78.7 \\
\hline $9 \mathrm{~m}$ & 72 & 71 & 71.3 & 72 & 72 & 71 & 72 & 69 & 72 & 72 & 72 & 72 & 72 & 72 & 72 & 72 & 72 & 71.3 & 72 & 70 & 71.3 \\
\hline $12 \mathrm{~m}$ & 65 & 65 & 65 & 65 & 65 & 65 & 65 & 65 & 65 & 65 & 65 & 65 & 65 & 65 & 65 & 65 & 65 & 65 & 65 & 65 & 65.5 \\
\hline $15 \mathrm{~m}$ & 60 & 60.4 & 59.8 & 60 & 60 & 59 & 60 & 59 & 60 & 60 & 60 & 60 & 59 & 59 & 60 & 59 & 60 & 59.7 & 60 & 59 & 59.7 \\
\hline $18 \mathrm{~m}$ & 55 & 54.4 & 54.4 & 54 & 55 & 54 & 55 & 52 & 54 & 54 & 54 & 55 & 55 & 54 & 54 & 55 & 55 & 54.4 & 55 & 52 & 54.2 \\
\hline $21 \mathrm{~m}$ & 49 & 49.2 & 49.3 & 49 & 49 & 49 & 49 & 48 & 49 & 49 & 50 & 49 & 49 & 50 & 49 & 49 & 49 & 49.1 & 50 & 48 & 49.1 \\
\hline $24 \mathrm{~m}$ & 45 & 44.2 & 44.6 & 44 & 45 & 45 & 44 & 44 & 45 & 45 & 45 & 45 & 44 & 44 & 44 & 45 & 45 & 45 & 45 & 44 & 44.6 \\
\hline $27 \mathrm{~m}$ & 39 & 39 & 39 & 39 & 39 & 39 & 39 & 39 & 39 & 39 & 39 & 39 & 39 & 39 & 39 & 39 & 39 & 39 & 39 & 39 & 38.7 \\
\hline $30 \mathrm{~m}$ & 35 & 35 & 35 & 35 & 35 & 35 & 35 & 34 & 35 & 35 & 35 & 35 & 35 & 35 & 35 & 35 & 35 & 35 & 35 & 34 & 34.8 \\
\hline Mean & 58 & 58 & 58 & 58 & 58 & 58 & 58 & 55 & 58 & 58 & 58 & 58 & 58 & 58 & 58 & 58 & 58 & 58 & 58 & 56 & 58.2 \\
\hline
\end{tabular}

Source: Author's Field Survey, 2016

Akata-1, Alafia oluwa-2, Arowomole-3, Caretaker-4, Idioro-5, Ijeru-6, Ijeru2-7, Low cost-8, Odokoto-9, Oke alapata-10.

Adenike-11, Aaje-12, isale afon-13, agboyin-14, adiatu-15, high court-16, okelerin-17, sabo-18, isaleora-19, papa alajiki-20

Noise was found to be a function of distance. It varies inversely with distance with a negative correlation of 0.851 . The coefficient of determination $\left(\mathrm{R}^{2}=0.996\right)$ posits that there is a high degree of overlap between the two. In essence, putting the electric generator far away from where humans stay or sleep during its use would solve the problems causable by noise. Abatement method to alleviate the effects of generator use may look simple until we are confronted with the standard plot sizes and multiple plot arrangement. In other words, an average high density standard plot would be too small to buffer a single electric generator effectively, if only distance is factored into the buffering. The situation becomes worse with multiple generators within a plot of such size. Again all the adjoining plots that houses residential units may have similar situation. This ultimately increases the density of electric generators within a relatively small area.

The implication of this can be much. Individual efforts alone may not be sufficient to buffer away both the noise and fumes originating from multiple electric generators coming from all 


\section{Macrothink}

directions within the neighborhood. Understanding of the wind movement and cohesive collaboration of the neighborhood residents in partnership with governmental solution can go a longer way to mitigate the problems of noise and fumes. Conscious environmental greening in terms of tree planting, adequate open spaces, parks and gardens which may increase the carrying capacity of the environment would assist in the local carbon capture and sequestration to deliver a better livable environment.

\subsection{Air Quality Implications of Generator Usage}

Complete or incomplete combustion of gasoline produces: carbon monoxide (CO), hydrogen cyanide $(\mathrm{HCN})$, hydrogen sulphide $\left(\mathrm{H}_{2} \mathrm{~S}\right)$, hydrogen fluoride $\left(\mathrm{H}_{2} \mathrm{~F}\right)$, Nitric oxide $(\mathrm{NO})$, Nitrogen dioxide $\left(\mathrm{NO}_{2}\right)$ and Sulphur dioxide $\left(\mathrm{SO}_{2}\right)$. Nevertheless, in this study, only carbon monoxide, nitric oxide and Sulphur dioxide were investigated.

Table 4. Tolerable Standard and Observed Average Air Pollutant Concentration

\begin{tabular}{|c|c|c|c|c|c|c|c|c|c|}
\hline \multirow[t]{2}{*}{ SN } & & \multicolumn{2}{|c|}{$\mathrm{CO}(\mathrm{mg} / \mathrm{m} 3)$} & \multicolumn{2}{|c|}{$\mathrm{SO} 2(\mathrm{mg} / \mathrm{m} 3)$} & \multicolumn{2}{|c|}{$\mathrm{NO} 2(\mathrm{mg} / \mathrm{m} 3)$} & \multirow[b]{2}{*}{ Exposure } & \multirow[b]{2}{*}{ Source } \\
\hline & Medium & Max & Observed & Max & Observed & Max & Observed & & \\
\hline 1 & Outdoor & 0.573 & \multirow[t]{5}{*}{27.32} & & \multirow[t]{5}{*}{8.98} & 0.0085 & \multirow[t]{5}{*}{4.85} & - & Average \\
\hline 2 & Ambient & 3.44 & & - & & - & & $8 \mathrm{hr}$ & US/EPA \\
\hline 3 & Outdoor & 7 & & - & & 0.004 & & $24 \mathrm{hr} / \mathrm{yr}$ & WHO \\
\hline 4 & Outdoor & 10 & & - & & - & & $8 \mathrm{hr}$ & WHO/EC \\
\hline 5 & Outdoor & 30 & & $350 \mathrm{ug} / \mathrm{m} 3$ & & - & & $1 \mathrm{hr}$ & WHO \\
\hline
\end{tabular}

Source: Adapted from Donney, (2011); ETC/ACM (2011)

The maximum environmental standard approved by the $\mathrm{WHO}$ for $\mathrm{NO}_{2}$ is $0.0085 \mathrm{mg} / \mathrm{m}^{3}$. The mean observed concentration of NO2 in the study was $4.85 \mathrm{mg} / \mathrm{m}^{3}$. Similarly, against the environmental standard of $7 \mathrm{mg} / \mathrm{m}^{3}, 27.32 \mathrm{mg} / \mathrm{m}^{3}$ of $\mathrm{CO}$ was observed. The standard for $\mathrm{SO}_{2}$ is $0.0035 \mathrm{mg} / \mathrm{m}^{3}$, but the mean average in the study was $8.98 \mathrm{mg} / \mathrm{m}^{3}$. Volatile organic compound was also high. The maximum tolerable level is $1.9 \mathrm{ppm}$, a high mean average of $134 \mathrm{ppm}$ was recorded (see table 5). Some ambiguity surrounds the measurement of hydrogen sulfide in that it is also a byproduct of biological decay such as from solid wastes. The mean average for the study is $1.98 \mathrm{mg} / \mathrm{m}^{3}$. The result of t-test depicts a significant margin between the maximum tolerable standard and the observed level of gas pollutants emitted from electric generators during their use at alpha of .05. This implies that the ambient air pollution caused by the usage of electricity is far above what human health can cope with over a long period. 


\section{Macrothink}

Table 5. Effluence from Electric Generator $\left(\mathrm{mg} / \mathrm{m}^{3}\right)$

\begin{tabular}{|l|l|l|l|l|l|l|l|l|l|l|l|l|l|l|l|l|l|l|l|l|}
\hline Area & $\mathbf{1}$ & $\mathbf{2}$ & $\mathbf{3}$ & $\mathbf{4}$ & $\mathbf{5}$ & $\mathbf{6}$ & $\mathbf{7}$ & $\mathbf{8}$ & $\mathbf{9}$ & $\mathbf{1 0}$ & $\mathbf{1 1}$ & $\mathbf{1 2}$ & $\mathbf{1 3}$ & $\mathbf{1 4}$ & $\mathbf{1 5}$ & $\mathbf{1 6}$ & $\mathbf{1 7}$ & $\mathbf{1 8}$ & $\mathbf{1 9}$ & $\mathbf{2 0}$ \\
\hline SO2 & 8.9 & 9.2 & 8.9 & 9.8 & 9.1 & 9.1 & 9.8 & 8.9 & 9.0 & 9.2 & 8.9 & 9.3 & 9.2 & 9.8 & 8.9 & 8.9 & 9.8 & 9.8 & 8.9 & 8.2 \\
\hline NO2 & 4.9 & 5.2 & 4.9 & 5.8 & 5.1 & 5.1 & 5.8 & 5.9 & 5.0 & 5.2 & 4.9 & 5.3 & 5.2 & 5.8 & 5.9 & 4.9 & 4.8 & 4.8 & 4.9 & 4.2 \\
\hline CO & 29 & 28 & 28 & 27 & 27 & 29 & 28 & 25 & 27 & 28 & 29 & 27 & 27 & 28 & 27 & 29 & 27 & 27 & 28 & 24 \\
\hline H2S & 2.2 & 2.3 & 2.8 & 2.7 & 2.4 & 2.2 & 2.3 & 1.7 & 2.1 & 2.1 & 2.2 & 2.3 & 1.9 & 1.9 & 2.1 & 2.1 & 1.9 & 1.9 & 2.1 & 1.8 \\
\hline VOC & 141 & 138 & 134 & 135 & 134 & 139 & 134 & 115 & 133 & 141 & 134 & 138 & 136 & 137 & 132 & 141 & 136 & 139 & 138 & 118 \\
\hline
\end{tabular}

Source: Author's Field Survey, 2014

Akata-1, Alafia oluwa-2, Arowomole-3, Caretaker-4, Idioro-5, Ijeru-6, Ijeru2-7, Low cost-8, Odokoto-9, Oke alapata-10.

Adenike-11, Aaje-12, isale afon-13, agboyin-14, adiatu-15, high court-16, okelerin-17, sabo-18, isaleora-19, papa alajiki-20

Cause-effect relationships that are well known includes the darkening of paint by hydrogen sulfide; the damaging of vegetation by sulfur dioxide, oxidants, fluorides, and ethylene; and the effect of carbon monoxide on the oxygen-carrying capacity of the blood (Katz, 1969). Sulfur dioxide is one of the principal contaminants that may cause eye irritation and respiratory tract infection. Visibility impairment is most likely to be caused by high concentration of soot or smoke particles, dust or photochemical aerosols in the atmosphere (Afolayan et al, 2014). Coping with regular use of electric generator is tantamount to taking a regular high dosage of slow poison. The health-related dangers of carbon monoxide poisoning as a result of operating electrical generators indoors were poorly appreciated, even by health workers. There is a need for wider public education on the subject in Nigeria, and especially in the mass media and at schools and hospitals (Afolayan et al, 2014).

\section{Treatment of Variables}

In all, 39 scaled variables were subjected to factor analysis (table 6). There were five linear composites generated out of which three were considered residual as they account for similar variables but with lower communalities. Generator Use Index (GUI) extracts $39.17 \%$ of the total variance of the data set. The variables that load highly under it are: fuel type (.995), incidence of power outage (.995), number of generator in a building (.992), Domestic use (.992), Regularity of electric generator use (.991), Distance of generator to building (.990), etc. Residents Livability Index (RLI) extracts $31.42 \%$ variance of the data set. The 
Table 6. Extracted Factors 2017, Vol. 6, No. 1

\begin{tabular}{|c|c|c|c|}
\hline \multirow[t]{2}{*}{ SN } & \multirow[t]{2}{*}{ Variables } & \multicolumn{2}{|c|}{ Factors } \\
\hline & & 1 & 2 \\
\hline 1 & Power Outage & $.992(3)$ & \\
\hline 2 & Gen Possession & $.957(9)$ & \\
\hline 3 & Use Regularity & $.991(4)$ & \\
\hline 4 & Work Hour/day & $.983(7)$ & \\
\hline 5 & Fuel used/day & $.986(6)$ & \\
\hline 6 & No of Gen in Building & $.992(3)$ & \\
\hline 7 & Gen Age (Month) & $.951(10)$ & \\
\hline 8 & Gen Service Regularity & $.982(8)$ & \\
\hline 9 & Fuel type & $.995(1)$ & \\
\hline 10 & Gen Distance to Building & $.990(5)$ & \\
\hline 11 & Domestic use & $.993(2)$ & \\
\hline 12 & Other use & $.758(14)$ & \\
\hline 13 & Expenditure on fuel & $.887(12)$ & \\
\hline 14 & Maintenance & $.888(11)$ & . \\
\hline 15 & Electrical appliance damaged & & $.996(1)$ \\
\hline 16 & Theft & & $.764(24)$ \\
\hline 17 & $\%$ Income spent on Generator & & $.960(9)$ \\
\hline 18 & Social effects & & $.995(2)$ \\
\hline 19 & economic effect & & $.981(7)$ \\
\hline 20 & Noise & & $.972(8)$ \\
\hline 21 & Smoke & & $.983(6)$ \\
\hline 22 & Wall defacing & & $.943(11)$ \\
\hline 23 & electric shock & $.882(13)$ & \\
\hline 24 & Nervous diseases & & $.921(14)$ \\
\hline 25 & Hearing Impairment & & $.801(22)$ \\
\hline 26 & Eye Irritation & & $.813(17)$ \\
\hline 27 & Respiratory Tract Infection & & $.811(18)$ \\
\hline 28 & Throat Irritation & & $.942(12)$ \\
\hline 29 & Asthma & & $.984(5)$ \\
\hline 30 & Migraine & & $.956(10)$ \\
\hline 31 & Nausea & & $.986(4)$ \\
\hline 32 & Dizziness & & $.926(13)$ \\
\hline 33 & Fatigue & & $.814(16)$ \\
\hline 34 & Coma/death & & $.822(15)$ \\
\hline 35 & Lead Poisoning & & $.798(23)$ \\
\hline 36 & Eye Impairment & & $.803(21)$ \\
\hline 37 & Insomnia & & $.988(3)$ \\
\hline 38 & Effluence & & $.806(20)$ \\
\hline
\end{tabular}




\begin{tabular}{|l|l|l|l|}
\hline 39 & Health effect & & $.808(19)$ \\
\hline
\end{tabular}

Source: Author's Computation, 2014

variables involved are: electrical appliances damaged (.986), social effects (.984), incidence of asthma (.956), dizziness (.942), fatigue (.926) etc.. The study therefore used the two indices above to study the relationship between the usage of electric generators and residents livability.

\section{Relationship between Generator Usage and Residents Livability}

The regression coefficient for GUI when regressed with Residents Livability Index (RLI) was -811. This reveals that GUI is important to the explanation of residents environmental Livability. In other words, there is a significant relationship between a livable environment and the relative incidence of electric generator use. This implies that, when it is desired that the environment be livable, one of the factors to be considered is adequacy of basic utilities such as electric power, which may be negatively skewed towards the high incidence of electric generator use. Fuel burnt, Power outage, regularity of domestic generator use, multiple use of generators in a building, closeness of a working generator to where people are, daily use of electric generator for a long number of hours and the use of old, poorly maintained generators among others in the order of listing has been observed to relate negatively to residents livability in the study.

Table 7. Summary of Regression Analysis

\begin{tabular}{|l|l|l|l|l|l|l|l|l|l|}
\hline SN & Dependent & Independent & R & R2 & F & P.Value & B & PValue \\
\hline $\mathbf{1}$ & RLI & GUI &.-811 & .658 & 19.011 & .000 & $\begin{array}{l}\text { Constant } \\
\text { GUI }\end{array}$ & $\begin{array}{l}4.300 \\
.535\end{array}$ & $\begin{array}{l}.153 \\
.000\end{array}$ \\
\hline
\end{tabular}

Sources: Author's computation, 2014.

$\mathrm{Y}=\mathrm{a}+\mathrm{bx}+\mathrm{e} \ldots \ldots \ldots . .$. Regression Equation

Where $\mathrm{Y}=$ Dependent Variable (Residents Livability Index)

$\mathrm{a}=$ Constant (4.300)

$\mathrm{b}=.535$ Regression coefficient of the relative incidence of generator use index (GUI)

Economic cost in terms of collateral damage of especially domestic electrical appliances, fuel expenditure, the purchase and maintenance of electric generators are on top of the list of electric generator induced livability problem. This is closely followed by the health problems associated with the inhalation of fumes produced by these generators: insomnia, nausea, asthma, migraine, throat irritation, and dizziness among others (see the ranking on table 6) in the order of listing are the livability variables that the usage of generator has direct effects on.

The ability to improve environmental livability is relatively dependent on sustainable utility provision. This is relative because other factors jointly contribute to environmental livability. Invariably, the members of the linear composite of the relative incidence of electric generator usage in the order that they have been listed are relatively important to the explanation of Environmental livability. The inference for this study is that when areas are well supplied with basic utility or services such as electricity in a sustainable way, they greatly enhance the 
economy, health and the social lives of the residents, thus; they have the chance of alleviating environmental nuisances and environmental related diseases. To understand the degree to which each of the linear composites of Relative incidence of electric generator use (GUI) independently influence the linear composites of Residents Livability (RLI). The regression model is calibrated. The equation is given by:

$\mathrm{Y}=\mathrm{a}+\mathrm{bx}$

$\mathrm{Y}_{=}$Residents Livability Index

$\mathrm{a}=$ Constant of the regression model

$b=$ Coefficient of partial regression of the relative incidence of electric generator use

$\mathrm{x}=$ Relative incidence of electric generator use.

The coefficient for the model calibration is on table 7. Substituting for the equation therefore:

$\mathrm{RLI}=4.3+0.535(\mathrm{GUI})$

This equation implies that; holding other things constant, a unit increase in the index of the relative incidence of electric generator use (GUI) will produce 0.535 decrease in residents livability (RLI). But, residents livability in this study was basically measured by economic efficiency of basic utility provision and its access by residents, absence of environmental contaminants as a result of electricity provision, state of health of residents with a particular concern for ailment which may arise from fuel combustion and pollutants produced by electric generator during its use and the incidence of social problems such as crime, crowding and other extrinsic effects of electric generator use. It thus follow that; decrease in the use of electric generators would positively affect residents economic efficiency, improve their health, alleviate environmental pollutants to reduce global environmental risks such as climate change, carbon footprint and environmental morbidity and improve socio-psychological balance in our cities.

\section{Concluding Remarks}

Electric generator usage is one of the most terrible human-induced threats to liveability in the contemporary cities of the developing world especially Nigeria. It rightly commands widespread policy and public attention. Along with other rapid changes associated with global population and economic growth, climate change strains existing weak points in health protection systems and calls for reconsideration of public health priorities. Exploration of alternative electric power source is an imperative. Communities are advised to provide sustainable electricity from ubiquitous environmental resources given their locals and particulars. Sustainable monitoring and control of environmental standards that assures quality air, city greening, noise abatement, water quality, temperature and so on should be put in good priority. Legal and administrative frameworks needed for their proper enforcement should be put in place. 


\section{Acknowledgement}

This is to acknowledge that this research was fully funded by the Senate Research Grant of the Ladoke Akintola University of Technology, Ogbomoso Oyo State, Nigeria. The participation of my students in the department of Urban and Regional Planning, LAUTECH during the data collection is also acknowledged and appreciated.

\section{References}

Afolayan Jide, Tokunbo Olajumoke, Federick Amadasun \& Theodore Isesele (2014). Knowledge and Attitude of Nigerian personnel working at Federal Medical Centre in Nigeria on Carbon Monoxide Poisoning from Electrical Power Generators: South African Family Practice, 56(3), 178-181. https://doi.org/10.1080/20786204.2014.936662

Andrews, David (2007). Emergency diesel standby generators of Wessex Water potential Contribution to dealing with renewable energy sources intermittency \& variability. 11. The Institution of Diesel and Gas Turbine Engineers.

Blumenthal, I. (2001) Carbon Monoxide Poisoning Journal of Sociological Medicine, 94(6), 270-272.

Chambers, N., Simmons, C., \& Wackernagel, M. (2000). Sharing Nature's Interest: Ecological Footprints as an Indicator of Sustainability. Earthscan, London ISBN 1-85383-739-3 (see also http://www.ecologicalfootprint.com)

Guy, K. M., Pimlott, J. K., Rogers, M., \& Cross, M. (1999). The new CO and smoke inhalation advisory service in the UK. Treatment of poisioning. Indoor Built Environment, 8, 199-202. https://doi.org/10.1177/1420326X9900800313

Gasman, J. D., Varon, J., \& Gardner, J. P. (1990); Revenge of the barbecue grill: Carbon monoxide poisoning. West J Med., 153(6), 656-657.

Hampson, N. B., \& Stock, A. L. (2006). Storm-related carbon monoxide poisoning: lessons learned from recent epidemics. Undersea \& Hyperbaric Medicine: Journal of the Undersea and Hyperbaric Medical Society, Inc 33(4), 257-63.

Iribhogbe, P. E., \& Erah, F. O. (2009) Carbon Monoxide Poisoning Nigeria: it is Time to Pay Attention. Portharcourt Medical Journal, 4(1), 88-91.

Kirby Alex (2004,). Pollution: A life and death issue. BBC News. http://news.bbc.co.uk/1/hi/sci/tech/4086809.stm. Retrieved 2008-01-31.

Kryter, Karl D. (1994). The handbook of hearing and the effects of noise: physiology, psychology, and public health. Boston: Academic Press. ISBN 0-12-427455-2.

McDonald, E. M., Shields, W., Frattaroli, S., et al. (2010) Carbon Monoxide Knowledge, Attitudes and Practices in Urban Households. Inj Prev., 16(s1), A175.

https://doi.org/10.1136/ip.2010.029215.626

Monfreda, C., Wackernagel, M., \& Deumling, D. (2004). Establishing national natural capital 
accounts based on detailed Ecological Footprint and biological capacity assessments. Land Use Policy, 21, 231-246. https://doi.org/10.1016/j.landusepol.2003.10.009

Nanaghan, Ben (2009) Tuesday 3 March, (2009), Nigeria's Electricity Woes. http://www.nairaland.com/243581/power-supply-nigeriaare-cursed.

Office for National Statistics (2006); Mortality statistics: cause. Review of the Registrar General on deaths by cause, sex and age, in England and Wales, 2005. London: Her Majesty's Stationery Office.

Oyedepo, S. O. (2012) Energy and Sustainable Development in Nigeria: the Way Forward. Energy, Sustainability and Society, 2, 15. https://doi.org/10.1186/2192-0567-2-15

Passchier-Vermeer, W., \& Passchier, W. F. (March 2000). Noise exposure and public health Environment Health Perspectives, 108(1), 123-131. https://doi.org/10.1289/ehp.00108s1123

Pichot, P. (1992). Noise, sleep and behavior. Bulletin de l'Academie nationale de medicine, 176(3), 393-9.

Stansfeld, S., Haines, M., \& Brown, B. (2000). Noise and Health in the Urban Environment. Reviews of Environmental Health Jan-June, 15(1-2), 43-82.

https://doi.org/10.1515/reveh.2000.15.1-2.43

Schmidt, Charles W. (2005). Noise that Annoys: Regulating Unwanted Sound. Environmental Health Perspectives, 113(1), A42-A44. https://doi.org/10.1289/ehp.113-a42

Schwatz, L., Martinez, L, \& Louie, J. (2010). An Evaluation of Carbon Monoxide Poison Education Program. Health Promotion Practice, 11(3), 320-324.

https://doi.org/10.1177/1524839908327732

Seleye-Fubara, D., Etebu, E. N., \& Athan, B. (2011) Pathology of Deaths from Carbon Monoxide Poisoning in Portharcourt: an Autopsy Study of 75 cases. Niger Journal of Medicine, 20(3), 337-340.

The World Bank, (2004), http://www.worldbank.org

United Nations Development Programme, 2004 http://www.undp.org

Wakefield, Julie (2002). Learning the Hard Way. Environmental Health Perspectives, 110(6). https://doi.org/10.1289/ehp.110-a298

Walker, T., \& Hay, A. (1999) Carbon Monoxide Poisoning is still an Under recognised Problem. BMJ., 319(7212), 1082-1083. https://doi.org/10.1136/bmj.319.7217.1082

\section{Copyright Disclaimer}

Copyright for this article is retained by the author(s), with first publication rights granted to the journal.

This is an open-access article distributed under the terms and conditions of the Creative Commons Attribution license (http://creativecommons.org/licenses/by/3.0/). 